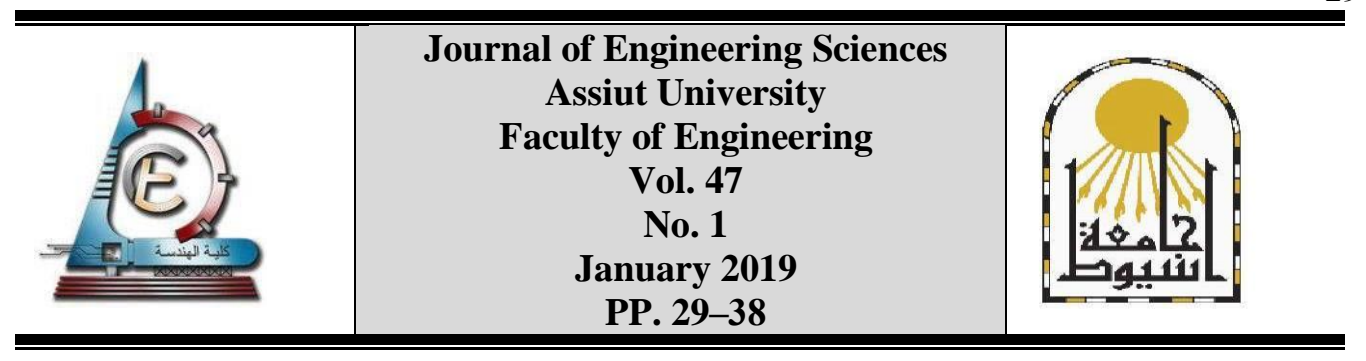

\title{
A STUDY ON THE CUSHIONING EFFECT OF CLAY ON THE COMMINUTION OF THE CEMENT RAW MEAL
}

\author{
Sherein Ahmed M. E. Rizk \\ Faculty of Engineering, Beni-suef University
}

Received 25 September 2018; Accepted 3 October 2018

\begin{abstract}
Growth and success of any industry on the whole, depends primarily on the market demands, efficient technology and availability of input resources.

In spite of development of different types of binders, cement continues to be the major building material for civil construction all over the world, as no other material is likely to substitute it in the near future.

The normal flow sheet for cement production, either by dry or wet operations begins with crushing of the two main components. Either limestone or shale are crushed separately then, ground simultaneously as a mixture ( $80 \%$ limestone and $20 \%$ shale) in a ball mill. This procedure consumes more energy in grinding due to the act of the shale as cushions between the grinding elements (balls) and the crushed limestone particles.

Consequently, the main objective of this investigation is to evaluate the cushioning effect of the shale during grinding the limestone and shale simultaneously as a mixture. It is confirmed that grinding the two components of the cement raw meal simultaneously as a mixture decreases the specific surface area of the product by $25 \%$ approximately. The relative suggestion is to grind these two components of the raw meal separately followed by adding blending unit before going to calciner.
\end{abstract}

Keywords: Cement raw meal -Comminution of heterogeneous materials -Cushioning effect in grinding mixtures.

\section{Introduction}

The major part of the raw materials to be processed by technological operations is not homogeneous but rather mixtures of various materials [1]. Extensive research work was carried out to investigate breakage characteristics of mono-sized single minerals in a laboratory mills [2-6]. However due to the actual grinding environment being never homogeneous in an industrial mill, the grinding characteristics of heterogeneous mineral systems also attracted lots of interests [2-3]. The research of heterogeneity systems can be classified into two directions. One in which the grinding of a mix of a single size fraction of two minerals with different size fractions, and the other direction in which the coarse size fraction is ground with fine particles of the same mineral [4-6].

In industry, situations arise in which materials of different physical characteristics are ground simultaneously in a ball mill. In some cases it might be commercially advantageous if milling could be carried out under conditions that imparted a desired particle size 
distribution to each of the two component materials. For example ores may need to be ground for liberation to sizes range for subsequent process efficiency [7].

Laboratory scale ball mill tests were carried out to investigate the influence of both the relative feed size and the percentage of the low grindability component on the performance and the preferential comminution [8]. The used samples were mixtures of limestone and quartz. Simultaneous grinding of these materials with varied percentages of the low grindability (quartz) showed that the percentage of batch grinding process decreases as the relative feed size and the percentage of the high grindability component (limestone) increases in the fine product as the percentage of the quartz increases and decreases as the relative feed size increases.

Experiments were carried out on a binary mixture composed of quartz as a representative for the hard component and limestone as a representative to the soft one at different compositions. Energy consumed for grinding quartz component, limestone component and their admixtures by ball mill was estimated [9]. It is found that, energy efficiency for grinding the mixture increases slightly and moderately for its soft component, but it decreases vigorously for the hard component in the mixture. It is also concluded that, energy efficiency of separate grinding of soft component is less than that if it is ground as admixture, but greater than with respect to the hard one.

The behavior of the selection and breakage functions was studied for coal-quartz binary mixture using the single size fraction method [10]. It was found that the selection function of coal equals 3.5 times of quartz when they ground separately. The selection function of the admixture decreases as the percentage of quartz in the mixtures increases.

Batch experiments were carried out on the dry milling of commonly used ceramics raw materials quartz, kaolin, and feldspar singly and as a ternary mixture [11]. The modified form of the Charles energy size reduction equation was used to calculate the energy consumed by each of the components. The results confirmed the validity of the mass fraction hypothesis for energy split between the components that had been defined and verified for the binary mixtures of equal density minerals.

The breakage kinetics and energetics of grinding coarse size feed in the presence of deliberately added fines for different material systems were compared [12].Quartz, dolomite and limestone mineral systems were selected as feed in order to study this phenomena for minerals whose hardness ranges from hard to soft. Approximately from 7 to 3 on Moh's scale of hardness at different coarse fine ratios. It was found that the cumulative breakage distribution functions for this situation do not change with mixture components for the three materials. On the other hand the initial breakage rate function of the coarse particles increases with increasing proportion of fines in the mixture. It was also shown that the fines product and the coarse material retained on the top sieve were normalizable with respect to the specific energy consumed by coarse fractions. It should be also noted that the size and shape of particles influence the breakage of mixtures [13].

Batch wet grinding studies were carried out by grinding of mono-sized fractions of quartz, chlorite binary mixture at different blending ratios [14]. The results obtained indicate that the breakage behavior of both minerals as well as their mixture followed a first order model. The maximum breakage rate for quartz and chlorite obtained in the feed size fraction of $-0.5+0.25$ $\mathrm{mm}$ were $0.19 \mathrm{~min}^{-1}$ and $0.33 \mathrm{~min}^{-1}$ respectively. It was also found that the breakage rate of quartz or chlorite had a linear relationship with the mass ratio in the binary mixture. 
Sherein Ahmed M. E. Rizk, A study on the cushioning effect of clay on the comminution of .......

The critical factors in the preparation of raw meal for the manufacture of portland cement include: correct proportioning, fine grinding and intimate mixing. All of these are controlled by vigilant chemical inspection and rigid inherence to the predetermined ideal composition for that plant. The dry process is especially well adapted to cement rock and to the mixture of limestone and shale or slate $[1,15-18]$.

Most of the existing cement plants are facing the problem of marjinal grade limestone or producing enormous quantity of low grade calcareous material which not only increase the quarrying cost but also causes environmental hazards because of huge dumps which occupy precious cultivable land [19].

The limestone used by Assiut Cement Company, contains generally fine fraction easily grinded, with a high content of $\mathrm{CaO}$, and a coarse fraction hardly grinded, which has a high content of $\mathrm{SiO}_{2}$. The hard fractions decrease the material grindability, while the fine and very fine fractions are difficult to be separated in the pre heaters cyclone towers. The decreasing of the effects generated by using this limestone has been possible by the taking of measure in all the technological phases of the clinkerization process [20-21].

Consequently, the main aim of this work is to confirm the act of the shale particles as a (plastic material) as cushions between grinding elements and limestone particles as a (brittle material) as well as the possibility of evaluating this act.

\section{Experimental work}

Samples of limestone and shale obtained from Assiut Cement Company were prepared separately using two jaw crushers in series, while the first was adjusted at an opening of 2 $\mathrm{cm}$; the second was adjusted at $1 \mathrm{~cm}$ opening. The needed size fractions as a feed for experiments according to the scheme of experimentation shown in Table (1) are (-10+8), ($8+6),(-6+4),(-4+2),(-2+1)$ and $(-1+00) \mathrm{mm}$. These fractions were prepared accurately for limestone and shale separately using a set of screens and vibrator.

A cylindrical ball mill of $14 \mathrm{~cm}$ length with as inside diameter of $16 \mathrm{~cm}$ driven by means of two rollers was used to perform the experimental work.

The operating factors affecting the grinding operation were kept constant at the following values:

Grinding media: round shape steel balls of $1.9 \mathrm{~cm}$ diameter, Volume of the mill occupied with charge: $50 \%$ of the total mill volume, $\mathrm{cm}^{3}$, Mill speed: $79 \mathrm{rpm}(70 \%$ of the critical speed), Grinding time: 7 minutes for each experiment (a suitable arbitrary time), Interstitial filling ratio: $90 \%$ where grinding is dry.

It should be noted that a ratio of 4:1 was kept constant for the experiments of mixture of limestone and shale respectively. At the end of each experiment a representative sample of the product was screened using a set of screens consisted of $10,8,6,4,3.15,2,1,0.8,0.63,0.50,0.315,0.200,0.100,0.071 \mathrm{~mm}$.

Specific surface area $\left(\mathrm{cm}^{2} / \mathrm{g}\right)$ was calculated for the product of each experiment. Results were evaluated by the specific surface area and also evaluated by the percentage of $-71 \mu \mathrm{m}$ in the product. 
Table 1.

Scheme of the experimental work

\begin{tabular}{|c|c|c|c|c|c|c|}
\hline Exp.No. & Ore type & $\begin{array}{c}\text { Size } \\
(\mathrm{mm})\end{array}$ & Exp.No. & Ore type & $\begin{array}{c}\text { Size of } \\
\text { limestone } \\
(\mathrm{mm})\end{array}$ & $\begin{array}{c}\text { Size of } \\
\text { shale }(\mathrm{mm})\end{array}$ \\
\hline 1 & Limestone & $-10+8$ & 19 & Mixture & $-8+6$ & $-10+8$ \\
2 & Limestone & $-8+6$ & 20 & Mixture & $-8+6$ & $-8+6$ \\
3 & Limestone & $-6+4$ & 21 & Mixture & $-8+6$ & $-6+4$ \\
4 & Limestone & $-4+2$ & 22 & Mixture & $-8+6$ & $-4+2$ \\
5 & Limestone & $-2+1$ & 23 & Mixture & $-8+6$ & $-2+1$ \\
6 & limestone & $-1+0.0$ & 24 & Mixture & $-8+6$ & $-1+0.0$ \\
\hline 7 & Shale & $-10+8$ & 25 & Mixture & $-4+2$ & $-10+8$ \\
8 & Shale & $-8+6$ & 26 & Mixture & $-4+2$ & $-8+6$ \\
9 & Shale & $-6+4$ & 27 & Mixture & $-4+2$ & $-6+4$ \\
10 & Shale & $-4+2$ & 28 & Mixture & $-4+2$ & $-4+2$ \\
11 & Shale & $-2+1$ & 29 & Mixture & $-4+2$ & $-2+1$ \\
12 & Shale & $-1+0.0$ & 30 & Mixture & $-4+2$ & $-1+0.0$ \\
\hline 13 & Mixture* & $-10+8$ & 31 & Mixture & $-1+0.0$ & $-10+8$ \\
14 & Mixture & $-8+6$ & 32 & Mixture & $-1+0.0$ & $-8+6$ \\
15 & Mixture & $-6+4$ & 33 & Mixture & $-1+0.0$ & $-6+4$ \\
16 & Mixture & $-4+2$ & 34 & Mixture & $-1+0.0$ & $-4+2$ \\
17 & Mixture & $-2+1$ & 35 & Mixture & $-1+0.0$ & $-2+1$ \\
18 & Mixture & $-1+0.0$ & 36 & Mixture & $-1+0.0$ & $-1+0.0$ \\
\hline
\end{tabular}

*Mixture of limestone and shale is $4-1$ by weight

\section{Results and discussions}

Results of ground limestone, shale, and their mixtures (80\% limestone $+20 \%$ shale) for the different studied size fractions are treated using two methods. They are the specific surface area $\left(\mathrm{A}_{\mathrm{CE}}\right)$ in $\mathrm{cm}^{2} / \mathrm{gm}$ that produced from Equation (1) as well as the percentage of $-71 \mu \mathrm{m}$ in the product.

\section{1. Analysis of the results based on the specific surface area $\left(A_{C E}\right)$ of the product}

The specific surface area of each ground product $\mathrm{A}_{\mathrm{CE}}$ was calculated for separate ground limestone, shale and their mixtures using Equation (1) [22-23] andthat for mixtures calculated from its separate components $\left(\mathrm{A}_{\mathrm{CS}}\right)$ are listed in Table $(2)$.

$\mathrm{A}_{\mathrm{CE}}=\frac{6 \lambda}{P_{P}} \sum_{n_{1}}^{n_{T}} \frac{\Delta \varphi_{n}}{D_{n}^{-}}$

Where:

$\mathrm{A}_{\mathrm{CE}}$ : the produced specific surface area, $\mathrm{cm}^{2} / \mathrm{gm}$,

$\lambda$ : The shape factor $=1.75$,

$P_{P}$ : Density of material, $\mathrm{gm} / \mathrm{cm}^{3}$,

$\mathrm{n}_{\mathrm{T}}$ : number of screens,

$D_{n}^{-}$: The arithmetic average of $\mathrm{D}_{\mathrm{Pn}}-\mathrm{D}_{\mathrm{P}(\mathrm{n}-1)}$,

$\mathrm{D}_{\mathrm{pn}}$ : the size of screen $(\mathrm{n}), \mu \mathrm{m}$,

$\varphi$ : mass fraction as a fraction of unity ,

$\sum \frac{\Delta \varphi_{n}}{D_{n}^{-}}$:The summation of all $\frac{\Delta \varphi_{n}}{D_{n}^{-}}$quantities of the individual fractions. 
Table. 2.

Produced specific surface area $\left(\mathrm{A}_{\mathrm{CE}}\right)$ for limestone, shale, and their mixtures and calculated specific surface area $\left(\mathrm{A}_{\mathrm{CS}}\right)$ for the mixture from its separate components.

\begin{tabular}{|c|c|c|c|c|c|}
\hline \multirow{2}{*}{$\begin{array}{l}\text { Size } \\
\text { fraction } \\
(\mathrm{mm})\end{array}$} & \multicolumn{3}{|c|}{$* \mathrm{~A}_{\mathrm{CE}}\left(\mathrm{cm}^{2} / \mathrm{gm}\right)$} & \multirow{2}{*}{$\begin{array}{c}* * \mathrm{~A}_{\mathrm{CS}} \\
0.8 \mathrm{~A}_{\mathrm{CE}} \text { limestone+0.2 } \\
\mathrm{A}_{\mathrm{CE}} \text { shale } \\
\left(\mathrm{cm}^{2} / \mathrm{gm}\right)\end{array}$} & \multirow{2}{*}{$\begin{array}{l}\mathrm{A}_{\mathrm{CS}}-\mathrm{A}_{\mathrm{CE}} \\
\left(\mathrm{cm}^{2} / \mathrm{gm}\right)\end{array}$} \\
\hline & limestone & shale & mixture & & \\
\hline$-10+8$ & 145.51 & 74.98 & 122.37 & $116.41+15=131.41$ & $131.41-122.37=9.04$ \\
\hline$-8+6$ & 187.62 & 92.33 & 125.30 & $150.10+18.47=168.57$ & $168.57-125.30=43.27$ \\
\hline$-6+4$ & 215.15 & 120.23 & 141.85 & $172.12+24.05=196.17$ & $196.17-141.85=54.32$ \\
\hline$-4+2$ & 288.08 & 154.79 & 200.77 & $230.46+30.96=261.42$ & $261.42-200.77=60.65$ \\
\hline$-2+1$ & 505.74 & 284.80 & 371.53 & $404.59+56.96=461.55$ & $461.55-371.53=90.02$ \\
\hline$-1+0.0$ & 889.26 & 611.78 & 705.21 & $\begin{array}{l}711.41+122.36= \\
833.77\end{array}$ & $833.77-705.21=128.56$ \\
\hline
\end{tabular}

$* \mathrm{~A}_{\mathrm{CE}}$ : specific surface area of the ground mixtures calculated by using Equation (1).

$* * \mathrm{~A}_{\mathrm{CS}}$ : specific surface area of the mixtures calculated from its separate components.

Produced specific surface area $\left(\mathrm{A}_{\mathrm{CE}}\right)$ for limestone, shale and their mixtures listed in Table (2) is represented in Fig. (1).

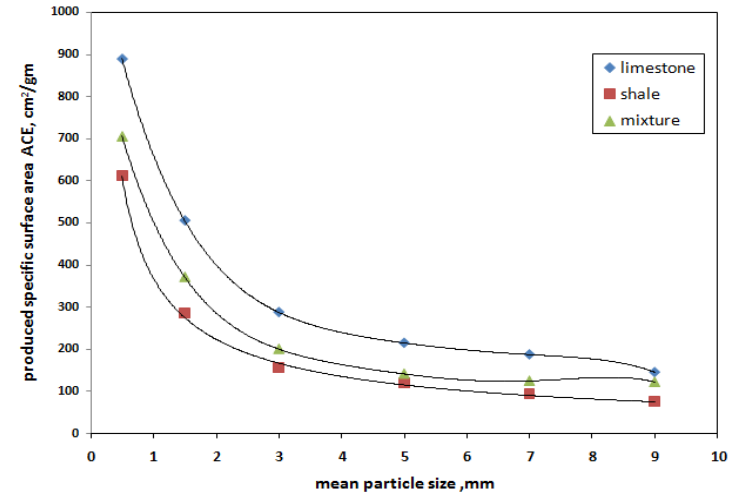

Fig. 1. The produced specific surface area $\left(\mathrm{A}_{\mathrm{CE}}\right)$ for limestone, clay and their mixtures.

From Fig.(1) it is clear that the produced specific surface area for limestone, shale and their mixtures increases as the particle size decreases. This behavior may be attributed to the decreasing the ratio of particle diameter to the ball diameter. Where diameter of particle $\left(\mathrm{d}_{\mathrm{p}}\right)$ to diameter of balls becomes $<0.2$ [24]. It can be also noticed that the produced specific surface area for limestone as a brittle material is higher than that for shale as a plastic material. On the other hand the specific surface area of the mixture is less than that of limestone and higher than that of shale due to the act of the shale particles as cushions between the grinding elements (balls) and limestone particles. This finding agrees with that obtained by Rizk and Ibrahim [25].

The percentage of lack in the specific surface area of the mixture $\left(\mathrm{A}_{\mathrm{CS}}-\mathrm{A}_{\mathrm{CE}}\right)$ and the particle size distribution of the mixture head sample are listed in Table (3). 
Table 3.

lack in the specific surface area as a percentage and the particle size distribution of the mixture head sample.

\begin{tabular}{|c|c|c|c|c|c|}
\hline $\begin{array}{c}\text { Size fraction } \\
(\mathrm{mm})\end{array}$ & $\begin{array}{c}\text { Lack } \\
\mathrm{A}_{\mathrm{CS}}-\mathrm{A}_{\mathrm{CE}} \\
\left(\mathrm{cm}^{2} / \mathrm{gm}\right)\end{array}$ & $\begin{array}{c}\mathrm{A}_{\mathrm{CE}} \\
\left(\mathrm{cm}^{2} / \mathrm{gm}\right)\end{array}$ & Lack \% & $\begin{array}{c}\text { Wt.\% } \\
\text { retained }\end{array}$ & $\begin{array}{c}\% \text { of lack } \\
\times \\
\text { Wt.\% retained }\end{array}$ \\
\hline$-10+8$ & 9.04 & 122.37 & 7.35 & 8.4 & 61.74 \\
$-8+6$ & 43.27 & 125.30 & 34.53 & 10.6 & 366.02 \\
$-6+4$ & 54.32 & 141.85 & 38.29 & 12.6 & 482.45 \\
$-4+2$ & 60.65 & 200.77 & 30.21 & 15.4 & 465.23 \\
$-2+1$ & 90.02 & 371.53 & 24.23 & 23.3 & 562.86 \\
$-1+0$ & 128.56 & 705.21 & 18.23 & 29.7 & 541.43 \\
\hline & & & & 100 & 2479.73 \\
\hline
\end{tabular}

From Table (3) it is clear that the percentage of lack in the specific surface area increases as the size fraction of mixture decreases. This behavior may be attributed to the increase of the shale particles number which creates a high chance for cushioning effect. The mean lack in the specific surface due to the cushioning effect can be evaluated as : $2479.73 / 100=24.8 \%$ approximately.

Results of the effect of shale mean particle size on the produced specific surface area of the mixture $\left(\mathrm{A}_{\mathrm{CE}}\right)$ at 7, 3, and 0.5 limestone mean size fractions are listed in Table (4) and represented graphically in Fig.(2).

Table 4.

Specific surface area of the mixtures $\left(\mathrm{A}_{\mathrm{CE}}\right)$ at varied mean size fractions of limestone.

\begin{tabular}{|c|c|c|c|c|c|c|}
\hline $\begin{array}{c}\text { Mean particle } \\
\text { size of shale (mm) }\end{array}$ & 9 & 7 & 5 & 3 & 1.5 & 0.5 \\
$\begin{array}{c}\text { Mean particle } \\
\text { size of limestone (mm) }\end{array}$ & & & & & & \\
\hline 7 & 246.49 & 225.51 & 218.06 & 206.71 & 199.21 & 85.65 \\
3 & 333.75 & 333.60 & 332.91 & 288.47 & 288.14 & 202.77 \\
0.5 & 744.66 & 733.60 & 728.46 & 723.72 & 719.37 & 711.46 \\
\hline
\end{tabular}

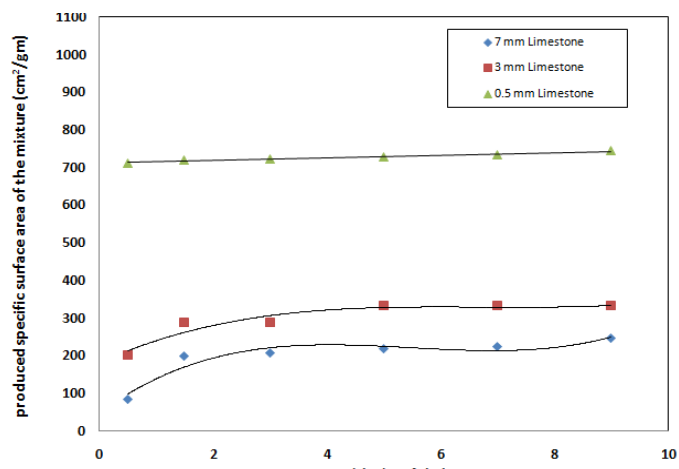

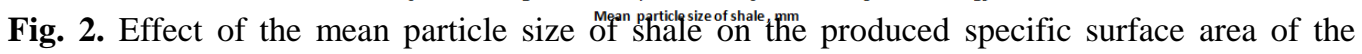
mixture at limestone mean size fractions of 7,3 and $0.5 \mathrm{~mm}$.

Figure (2) elucidates that the produced specific surface area of the mixture increases as the mean size fraction of limestone decreases. This behavior may be attributed to the decrease of 
Sherein Ahmed M. E. Rizk, A study on the cushioning effect of clay on the comminution of ......

the particle diameter to ball diameter ratio. The results trend agrees with that obtained by Oksizoglu [5]. It is also noticed that the produced specific surface area of the mixture increases slightly with increasing the shale mean particle size especially for coarse fractions of limestone.

\subsection{Analysis of the results based on the percentage of $-71 \mu \mathrm{m}$ in the product}

The same results are analyzed based on the percentage of $-71 \mu \mathrm{m}$ in the products. These results for separate ground limestone, shale and their mixtures are listed in Table (5) and represented graphically in Fig. (3).

Table 5.

Percentage of $-71 \mu \mathrm{m}$ in the ground limestone, shale and their mixtures.

\begin{tabular}{|c|c|c|c|c|c|}
\hline $\begin{array}{c}\text { Size } \\
\text { fraction } \\
(\mathrm{mm})\end{array}$ & \multicolumn{2}{|c|}{$-71 \mu \mathrm{m}$ in the product } & $\begin{array}{c}-71 \% \text { in the ground } \\
\text { mixture calculated } \\
\text { from its separate } \\
\text { components }\end{array}$ & $\begin{array}{c}\text { Calculated separate } \\
\text {-produced } \\
\%\end{array}$ \\
\hline$-10+8$ & 10.40 & 4.17 & 8.35 & $8.32+0.83=9.15$ & $9.15-8.35=0.8$ \\
$-8+6$ & 13.41 & 5.13 & 8.55 & $10.73+1.03=11.76$ & $11.76-8.55=3.21$ \\
$-6+4$ & 15.38 & 6.68 & 9.68 & $12.30+1.34=13.64$ & $13.64-9.68=3.96$ \\
$-4+2$ & 20.59 & 11.25 & 13.77 & $16.47+3.03=19.50$ & $19.50-13.77=5.73$ \\
$-2+1$ & 33.18 & 13.3 & 23.01 & $26.54+2.66=29.20$ & $29.20-23.01=6.19$ \\
$-1+0.0$ & 67.89 & 28.8 & 53.05 & $54.31+5.76=60.07$ & $60.07-53.05=7.02$ \\
\hline
\end{tabular}

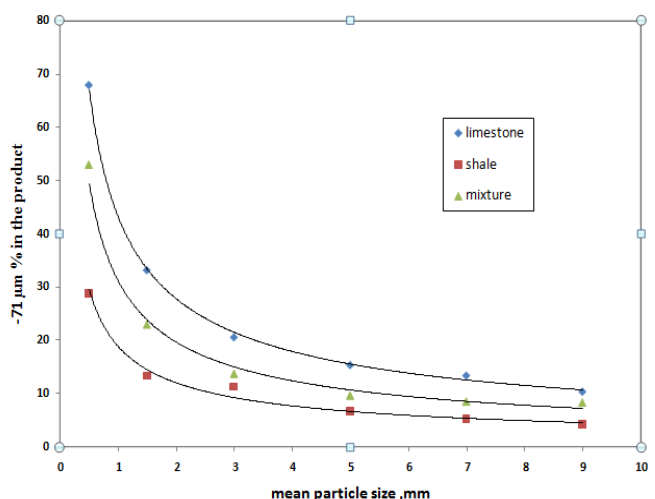

Fig. 3. Percentage of $-71 \mu \mathrm{m}$ in the ground limestone, shale and their mixtures.

It is clear from Fig.(3) that percentage of $-71 \mu \mathrm{m}$ decreases in the product as the size fractions increase for limestone, shale and their mixtures. It is noticed that the results trend agrees with that of Fig.(1).

Results of the effect of shale mean particle size on the percentage of $-71 \mu \mathrm{m}$ in the ground mixture at 7, 3 and 0.5 limestone mean size fractions are listed in Table (6) and represented graphically in Fig.(4).

Table 6.

Percentage of $-71 \mu \mathrm{m}$ in the ground mixtures at varied mean size fractions of limestone.

\begin{tabular}{|c|c|c|c|c|c|c|}
$\begin{array}{c}\text { Mean particle } \\
\begin{array}{l}\text { Mean particle of shale (mm) } \\
\text { size of limestone (mm) }\end{array}\end{array}$ & 9 & 7 & 5 & 4 & 1.5 & 0.5 \\
\hline 7 & 16.05 & 15.56 & 14.38 & 13.53 & 13.34 & 12 \\
3 & 24.62 & 23.92 & 23.16 & 22.52 & 20 & 17.6 \\
0.5 & 57.06 & 55.24 & 54.49 & 54.02 & 53.99 & 53.11 \\
\hline
\end{tabular}




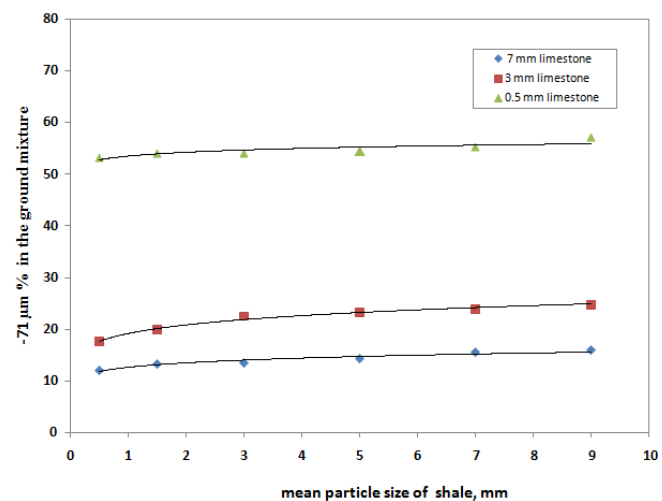

Fig. 4. Effect of the mean size fraction of shale on the production of $-71 \mu \mathrm{m}$ in the mixtures at varied mean sizes of limestone.

Figure (4) elucidates that the production of $-71 \mu \mathrm{m}$ in the ground mixture is slightly affected by increasing the shale size fractions. On the other hand this production increases with decreasing the limestone size fractions. It is noticed that the trend of these results is in a good agreement with that obtained in Fig.(2).

\section{Conclusions}

From the obtained results and their discussions the following conclusions can be drawn:

- Grinding the two components of the cement raw meal separately is more reasonable than their grinding simultaneously as a mixture. Where grinding them as a mixture decreases the specific surface area of the product by $25 \%$ approximately due to the act of shale as a cushion between the grinding elements (balls) and limestone particles.

- Changing the mean size fractions of the shale in the mixture has a slight effect on the produced specific surface area of the ground mixture.

- Analysis of the results based on the specific surface area agreed with that based on the percentage of $-71 \mu \mathrm{m}$ in the ground mixture.

- It is recommended to add a blending unit after grinding limestone and shale separately for intimate mixing before going to the calciner.

\section{Acknowledgement}

The author gratefully acknowledges the encouragement, assistance and co-operation of mineral processing staff members of Mining and Metallurgical Engineering Department in Assiut University.

\section{REFERENCES}

[1] Juhasz, A.Z., and Opoczky,L., "Mechanical activation of minerals by grinding" John Wiley and Sons, New York, (1990).

[2] Shinwani, D, Glasser, D., Hidebrandt, M.J., Metzager, F.K., and Mulenga, F.K., "Determination of milling parameters of a platinum group minerals ore to optimize product size distribution for flotation purpose" Miner. Eng.43-44 (2013) 67-78.

[3] Palaniandy, K.A.M., Hussin, A.H., and Hashim, S.F.S., "Study on the mechanical effect of silica for short grinding period", Int.J.Min.Process., 82 (2007) 195-201.

[4] Fuerstenau, D.W., Abouzeid, A.Z.M., and Phatak, P.B, "Effect of particulate environment on the kinetics and energetics of dry ball milling", Int.J.Min.Process., 97 (2010) 52-58. 
Sherein Ahmed M. E. Rizk, A study on the cushioning effect of clay on the comminution of .......

[5] Oksizoglu, M., "An experimental study on the ultra-fine grinding of gypsum ore in a dry ball mill", Powder Technol., 291 (2016) 186-197.

[6] Tangsathitkulchai, C., "Acceleration of particle breakage rates in wet batch ball milling", Powder Technol., 124 (2007) 67-75.

[7] Rose, H.E., and Matsumura, S., "Simultaneous grinding of two materials in a batch ball mill", Trans. Instn. Min. Metall. (Sect.c:Mineral Process. Extr-Metall.), (1985), pp. C40-C46.

[8] Rizk, A.M.E., "The influence of the feed particle size on the preferential comminution of binary mixture", Al-AzharEngng. Second International Conference, AEC 91, Dec. 21-24, (1991).

[9] Abdel-Haffez, G.S., Abu-Ali, M.H., and Rizk, A.M., "Assessment of energy efficiency of energy consumption in binary mixture grinding", J. of Engng. Science, Assiut University, Vol. 33, No.6(2005), pp. 2281-2296.

[10] Rizk, A.M., and Abuel-Kassem, M., "Behavior of the selection and breakage functions of coal-quartz binary mixture", Bull. Of the faculty of Engng. Assiut University, Vol.21, No.1, Jan. (1993).

[11]Ipek, H., Ucbas, Y., and Hosten, C., "Ternary-mixture grinding of ceramic raw materials", Min.Eng., 18 (2005) 45-49.

[12] Fuerstenau, D.W., Phatalo, P.B., kapur, P.C., and Abouzeid, A-Z.M. "Simulation of the grinding of coarse/fine (heterogenous) systems in a ball mill", Int.J.Miner. Process. 99 (2011) 32-38.

[13] Norazirah, A., Fuad, S.H.S., and Hazizan, M.H.M., "The effect of size and shape on breakage characteristic of mineral", Procedia Chemistry 19 (2016) 702-708.

[14]Zahao, R., Han., Y., He, M., and Li, Y., "Grinding kinetics of quartz and chlorite in wet ball milling", Powder Technol., 305 (2017) 418-425.

[15]Bogue, R.H., "The chemistry of Portland cement", Second Ed., Reinhold Publishing Corporation, New York, (1955), pp.40-46.

[16] Soni, S.K., "Building materials and construction", Published by S.K. Kataria and sons, Newdlhey, (2016), pp.97-100.

[17] Makrom, H.A., "Technology of the cement industry", Tura Cement Egyptian Company, General Management of Training, Part (1), (1994).

[18]PAA/Bern, "Cement industry", Assiut Cement Company, (CEMEX), (2003).

[19] Raina, S.J., Imran, M., Sotecha, S.K., and Sharma, N.K., "Utilization of sub-grade limestone for cement manufacture", First International Symposium on Cement Industry, Part I, Assiut, Egypt, 8-10 Nov. (1997).

[20] Shanawany, A., Toader, A., Sandry, C., and Bellei, E., "Characteristics of row materials in Assiut Cement Company, Egypt, First International Symposium on Cement Industry, Part I, Assiut, Egypt, 8-10 Nov.(1997).

[21] Rizk, A.M.E., and Mabrouk, S.A., "Some aspects of the limestone crushing system in Assiut Cement Company", Bull. Of the Faculty of Engng. Assiut University, Vol. 20, No.1, Jan.(1992).

[22] Palik, E.S., "Specific surface area measurements on ceramic powders", Powder Techn., 18 (1977) 45-48.

[23] Glaves, C.L., Davis, P.J., and Smith, D.M., "Surface determination via NMR: Fluid and frequency effect", Powder Techn., 54 (1988) 261-269.

[24] Chimwani, N., Mulenga, F.K., and Hildebrandt, D., "Ball size distribution for the maximum production of a narrowly-sized mill product", Powder Technology, 284 (2015) 12-18.

[25] Rizk, A.M., and Ibrahim, G.A., "The dependence of the production of fines on the grinding regime of the cement raw meal", Bull. of the Faculty of Engng. Assiut University, Vol.19 No.1, Jan. (1991). 
دراسة عن تأثير عمل الطفلة كوسادات على طدن وجبه فرن الأسمنت

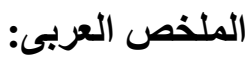

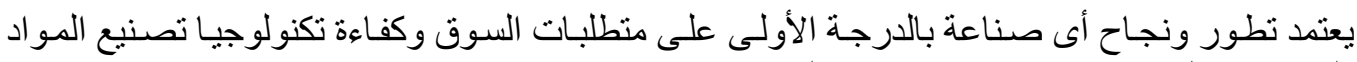

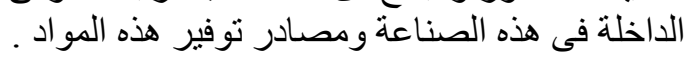

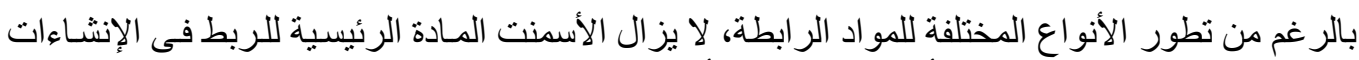

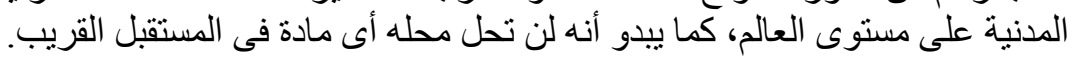

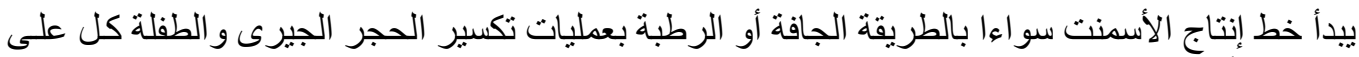

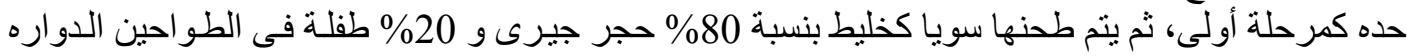
ذات الكرات كوسط طاحن و التى تسمى بطو احين الخام.

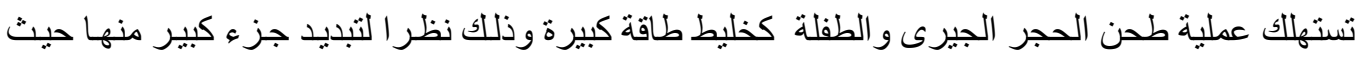

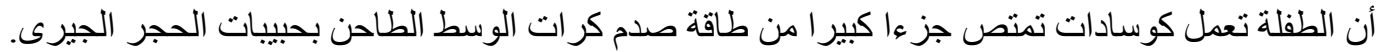
ومن ثم، فالهدف الرئيسى لهذا البحث هو إثبات عمل الطفلة كوسـادات بين حبيبات الحجر الجيرى عند النداء

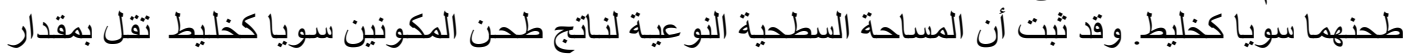

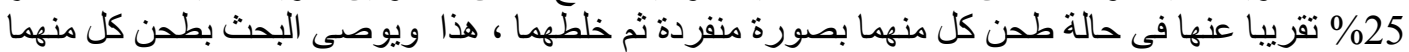

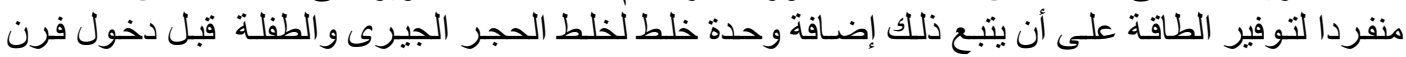

